\title{
JANELAS DE LIBRAS E GÊNEROS DO DISCURSO: APONTAMENTOS PARA A FORMAÇÃO E ATUAÇÃO DE TRADUTORES DE LÍNGUA DE SINAIS
}

\section{BRAZILIAN SIGN LANGUAGE WINDOW AND SPEECH GENRES: POINTING FOR SIGN LANGUAGE TRANSLATORS TRAINING AND WORK}

\section{Vinícius Nascimento*}

\section{RESUMO}

Discute-se, neste artigo, os aspectos da inserção da janela de língua brasileira de sinais (Libras) em produções audiovisuais a partir das especificidades dos gêneros do discurso a serem mobilizados pela tradução, bem como seus efeitos para a formação de tradutores e intérpretes do par linguístico Libras/Língua Portuguesa (LP). Com base na teoria dos gêneros do discurso elaborada por Mikhail Bakhtin e seu Círculo, discute-se que a acessibilidade linguística para surdos em materiais audiovisuais com a inserção da janela de Libras clama por uma discussão para além dos parâmetros técnicos de captação da imagem do tradutor e da sua inserção na produção midiática. Faz-se necessário discutir as especificidades enunciativo-discursivas do vídeo fonte para dar à janela de Libras a dimensão de acabamento (tamanho, recorte, posição) a partir das especificidades do gênero. Para comprovar esta tese, analisa-se produções de dois gêneros com janela de Libras que foram produzidas em um curso de pós-graduação lato sensu para tradutores e intérpretes de Libras/Português.

Palavras-chave: Tradução, Janela de Libras, Verbo-visualidade.

\section{ABSTRACT}

In this article, we discuss the aspects of the Brazilian Sign Language (Libras) window insertion into audiovisual productions based on the specificities of the speech genres mobilized in the translation activity, as well as their effects on Libras/Portuguese translators and interpreters training. We are using the conception of speech genres elaborated by Mikhail Bakhtin and his Circle to theoretical discussion. It is argued that the linguistic accessibility for Deaf people by the Libras window insertions in videos needs a discussion beyond the technical parameters of image capture of the translator and/or the interpreter the insertion of space into production. It is necessary to discuss the enunciative-discursive specificities of the source video to give the Libras window the dimension of finishing (size, cut, position) from the genre specificities. To prove this thesis, we analyze productions of two genres with Libras window that were produced in a Libras/Português translators/interpreters course. Keywords: Translation, Sign Language Window, Verbal-visuality.

\footnotetext{
* Universidade Federal de São Carlos, São Carlos, SP. Brasil. nascimento_v@ufscar.br http://dx.doi.org/10.1590/010318138649203273941
} 


\section{INTRODUÇÃO}

Nas eleições municipais de 2016 as redes televisivas, os partidos políticos e os candidatos à prefeitura e à vereança em todo o Brasil tiveram de se adaptar - $\mathrm{e}$ se submeter - à Lei Brasileira de Inclusão (LBI) 13.146, que instituiu o Estatuto da Pessoa com Deficiência. A LBI, sancionada no dia 6 de julho de 2015, intensificou a política inclusiva para pessoas com deficiência iniciada nos anos 1990 e foi um ganho para toda a sociedade brasileira. Dentre as determinações, destaca-se, no $67^{\circ}$ artigo, que "os serviços de radiodifusão de sons e imagens devem permitir o uso dos seguintes recursos, entre outros: I - subtitulação por meio de legenda oculta; II - janela com intérprete da Libras; III - audiodescrição" (BRASIL, 2015 p. 37). No capítulo IV, Do Direito à Participação na Vida Pública e Política, em seu artigo 76, a LBI salienta que "o poder público deve garantir à pessoa com deficiência todos os direitos políticos e a oportunidade de exercê-los em igualdade de condições com as demais pessoas" e no item III desse mesmo artigo a lei diz, ainda, que o poder público deve promover essa participação por meio da "garantia de que os pronunciamentos oficiais, a propaganda eleitoral obrigatória e os debates transmitidos pelas emissoras de televisão possuam, pelo menos, os recursos elencados no art. 67 desta Lei" (BRASIL, 2015, p. 39).

A nova realidade de acessibilidade para surdos em vídeos político-partidários estabelecida pela LBI fez com que uma diversidade de formatos, tipos, cores, tamanhos e recortes de janelas fossem inseridas nas propagandas partidárias obrigatórias e nos debates municipais promovidos pelas diferentes emissoras de TV em 2016. A pluralidade dessas inserções pode ser atribuída, dentre outros aspectos, ao fato de que, antes da LBI, poucos candidatos ou partidos adotavam o uso desse recurso em suas produções audiovisuais publicitárias. Por isso, a pressa, a falta de conhecimento técnico por parte dos editores, o desconhecimento da Norma da ABNT 15.290 - que estabelece parâmetros técnicos de acessibilidade na televisão - e a emergência para o cumprimento da lei para evitar a proibição da veiculação da propaganda dos partidos e candidatos fez com que o horário político fosse, na realidade, um "show de horrores" para os eleitores surdos. Os problemas foram tantos que a Federação Brasileira das Associações de Tradutores, Intérpretes e Guias-Intérpretes da Língua de Sinais (FEBRAPILS) criou um formulário para reunir as denúncias de janelas irregulares a fim de direcionar as inadequações aos Tribunais Regionais Eleitorais (TREs). E em parceria com a Federação Nacional de Educação e Integração de Surdos (FENEIS), a FEBRAPILS emitiu a Nota técnica sobre a atuação do tradutor, intérprete e guia-intérprete de Libras e Lingua Portuguesa em materiais 
audiovisuais televisivos e virtuais ${ }^{1}$ orientando profissionais da área, editores, produtores e a comunidade surda em geral sobre os aspectos ligados à inserção da janela de Libras, sobre os processos de tradução e de interpretação e outros detalhamentos.

Somada à nova realidade das propagandas político-partidárias impulsionada pela LBI, a Agência Nacional do Cinema (ANCINE) emitiu, em 2016, uma Instrução Normativa (I.N. No .128 ) com normas e critérios básicos de acessibilidade visual e auditiva a serem observados nos segmentos de distribuição e exibição cinematográfica. No artigo $3^{\circ}$ da I.N pode-se ler que "as salas de exibição comercial deverão dispor de tecnologia assistiva voltada à fruição dos recursos de legendagem, legendagem descritiva, audiodescrição e LIBRAS - Língua Brasileira de Sinais". $\mathrm{O}$ uso dos três recursos configura a aplicação do princípio da redundância que visa estabelecer, conforme descrevem Torres e Mazzoni (2007, p. 77), que "informação acessível é aquela que pode ser captada de forma multissensorial". Esse princípio prevê, portanto, que os recursos de acessibilidade apontados pela instrução normativa da ANCINE não apenas podem como devem ser oferecidas aos diferentes telespectadores brasileiros. A decisão da ANCINE foi importante para a ampliação dos públicos surdo, cego, deficiente auditivo e deficiente visual à produção cultural audiovisual cinematográfica.

Com a expansão da oferta de produções audiovisuais acessíveis incentivadas pelo poder público e a necessidade, cada vez mais urgente, de pensar práticas tradutórias e interpretativas da língua de sinais em materiais audiovisuais, se fazem necessárias discussões sobre os espaços (nos vídeos e nos documentos legais) das janelas de Libras e sobre a atuação de tradutores e de intérpretes nesse novo contexto. Nas produções audiovisuais acessíveis - tanto as que iniciaram timidamente com a Lei de Acessibilidade, 10.098/00 como as recentes propagandas político-partidárias - a inserção da janela de Libras em materiais midiáticos de diferentes tipos tem sido promovida, apenas, com base na captação e edição da imagem do tradutor e do intérprete e não nas especificidades dos gêneros do discurso e da recepção e circulação dessa produção entre os surdos. Esse aspecto vai além da necessidade de produtoras e editores se adaptarem tecnicamente em relação a essa nova realidade, mas reverbera, sobretudo, na dimensão formativa de tradutores e de intérpretes para atuarem nessa esfera, já que estes são os profissionais que realizam os processos tradutórios e interpretativos da Libras nas diferentes esferas sociais.

Algumas pesquisas têm se dedicado à compreensão dos aspectos ligados à atuação dos tradutores e dos intérpretes de língua de sinais (TILS) em produções audiovisuais e midiáticas, bem como suas devidas repercussões na comunidade

1. Disponível em: http://www.febrapils.com.br/2017/04/nota-tecnica-materiais-audiovisuais.html 
surda. Em nossa pesquisa de mestrado (NASCIMENTO, 2011) buscamos descrever as especificidades do gênero jornalístico televisivo e de que forma os elementos verbo-visuais desse gênero interferem e/ou contribuem para a atuação do tradutor e do intérprete de língua de sinais em mídias. Em outras pesquisas sobre o tema, temos buscado compreender os efeitos diretos desses elementos na construção de sequências didáticas para a formação desses profissionais envolvendo esses gêneros (NASCIMENTO, 2014) e como o princípio da redundância, que pressupõe a inserção simultânea da janela de Libras, da legenda em português e da audiodescrição, delineia o acabamento específico da acessibilidade comunicacional na esfera televisiva (NASCIMENTO, 2016b).

Brito (2012), por sua vez, buscou investigar a integralidade dos sistemas de acessibilidade para surdos em produções audiovisuais, especialmente o uso de legenda em português e a janela de Libras. O pesquisador caracterizou diferentes perfis de surdos a partir de fatores físico-biológicos, que são relacionados ao tipo e momento do diagnóstico da surdez, e de fatores linguístico-culturais, que representam o ambiente social em que ocorre o desenvolvimento do sujeito surdo. Esses fatores têm ampla variação e possibilidade de combinação e, dessa forma, percebe-se que não é possível determinar um único tipo de surdo usuário de recursos acessíveis. $\mathrm{O}$ autor, então, concluiu que

a oferta de acessibilidade deve considerar que a escolha dos tipos de recursos a serem usados para um acesso efetivo deve ser feita pelo próprio surdo. Pode existir o surdo ensurdecido, que tem preferência exclusiva pela legenda em língua oral escrita, e em outro extremo o surdo que não possui referências à língua oral e prefere usar a LS [língua de sinais] para sua comunicação. (BRITO, 2012, p. 289)

A pesquisa de Faria e Silva (2016, p. 73) caminhou, também, na direção de investigar quais são as preferências dos surdos frente aos recursos de acessibilidade disponíveis. Por meio de entrevistas, os pesquisadores observaram que, diferente do que se pressupunha, os surdos preferem o recurso da legenda em detrimento da janela, e o motivo é apenas um: "a janela quase impossibilita assistirem o que se passa na TV". Seja pela ausência, seja pela edição mal realizada, a janela de Libras é observada, por alguns surdos, como um desejo ainda a ser alcançado, visto que as ofertas desse recurso até hoje não foram a contento.

Albres $\left(2015 \mathrm{a}_{i} 2015 \mathrm{~b}\right)$ tem se dedicado à análise dos processos de tradução e de interpretação da Libras em literaturas infanto-juvenis. A pesquisadora tem se preocupado em mapear a construção de personagens, o uso do espaço e aspectos constitutivos dos processos de tradução a partir das marcas de verbo-visualidades das narrativas multimodais gráficas. Os estudos de Albres apontam para a necessidade 
de se pensar, nesse sentido, em um direcionamento de janelas específicas para esse tipo de gênero.

Nichols (2016) discutiu a recepção de literatura infanto-juvenil por crianças surdas por meio de materiais audiovisuais. A partir de estudos psicanalíticos, o pesquisador observou três modelos de histórias traduzidas para a língua de sinais e seus efeitos subjetivos em crianças surdas. No primeiro modelo, o vídeo insere a imagem do narrador na tela cheia com fundo neutro e sem imagem; o segundo traz o narrador em janela pequena e o fundo com imagem; e o terceiro vídeo tem o narrador em balão ao lado do texto e, também, possui fundo com a imagem. As histórias foram apresentadas para os alunos do quinto ano de uma escola particular bilíngue para surdos de um município do estado de São Paulo. Os alunos assistiram às fábulas e sinalizaram e responderam em grupo, a perguntas realizadas pelo pesquisador. Com base em observações das enunciações dos alunos surdos, analisou-se sua compreensão, verificando, também, como a literatura influencia sua constituição subjetiva. O estudo de Nichols (2016) contribui, junto com os estudos de Albres, para a tradução e o papel da literatura infanto-juvenil para as crianças surdas com diferentes modos de exibição de vídeos e janelas.

Diante da tímida produção acadêmica sobre o assunto, este artigo se propõe a discutir aspectos da inserção da janela de Libras em produções midiáticas a partir das diferenças e especificidades dos gêneros do discurso a serem mobilizados por meio de tradução ${ }^{2}$ da língua de sinais. Analisam-se materiais acessíveis produzidos como atividade avaliativa final de uma disciplina sobre o tema em um curso de pósgraduação lato sensu de Tradução e Interpretação de Libras/Português demonstrando que a inserção da janela de Libras a partir das especificidades do gênero e das esferas de recepção e circulação dos materiais audiovisuais podem ser pensadas pelos tradutores e intérpretes que atuam com o par linguístico Libras/LP em parceria com os produtores dos materiais realizados. Para essa discussão, utiliza-se a teoria

2. Neste artigo, discutiremos a tradução e não a interpretação da língua de sinais. Segundo Nascimento (2016) e Pagura (2003), a tradução dedica-se à mobilização de textos em um espaço-tempo expandido, recursivo e com possibilidade de pesquisa para aprimoramento dos enunciados por parte de quem a realiza, bem como a de revisão final do produto traduzido; a interpretação, ao contrário, é efêmera, é produzida no imediatismo das interações face-a-face, no "aqui e agora", nos textos produzidos nos e pelos atos de fala, em um espaço-tempo reduzido. Neste artigo, discutese a mobilização discursiva de textos pré-existentes de uma língua a outra a partir de gêneros que circulam em diferentes esferas e suportes midiáticos, sendo possível traçar um planejamento sobre essa mobilização, ou seja, o foco aqui será a tradução. Todavia, é preciso salientar que a interpretação também pode ocorrer em diferentes esferas e suportes midiáticos como em programas ao vivo, por exemplo, ou em grandes conferências em que o intérprete é captado em estúdio e projetado em uma grande tela para o público. Nesse último caso, a mobilização discursiva entre línguas distintas acontece em um espaço tempo limitado, efêmero e não recursivo. 
bakhtiniana dos gêneros do discurso e as devidas leituras para análise de práticas discursivas tradutórias envolvendo a dimensão verbo-visual em diferentes mídias e gêneros.

\section{GÊNEROS DO DISCURSO, PRÁTICAS DISCURSIVAS VERBO-VISUAIS E TRADUÇÃOO}

Para defendermos a tese de que as janelas de Libras podem ser inseridas de acordo com as peculiaridades e direcionamentos dos gêneros discursivos a serem traduzidos e não apenas pelas normas impositivas de acessibilidade, visitaremos a teoria bakhtiniana sobre os gêneros do discurso. Denomina-se pensamento bakbtiniano, perspectiva bakbtiniana e perspectiva dialógica a maneira como Mikhail M. Bakhtin, em diálogo com outros intelectuais russos no início do século XX, conceberam a linguagem no âmbito da cultura, da literatura, da estética, das artes e da comunicação, contribuindo, de maneira direta, com as Ciências Humanas em geral. O legado teórico deixado pelas reflexões de Bakhtin e seu Círculo podem ser observadas em diferentes campos do conhecimento sendo, portanto, um profícuo e produtivo conjunto de apontamentos filosóficos e teórico-metodológicos que podem ser adotados na leitura, análise e enfrentamento de diferentes corpora de dimensão verbal, visual, verbo-visual, oral, gestual, escrito e etc. (BRAIT, 2008, 2013; NASCIMENTO, 2016).

Os conceitos de esferas da atividade e gêneros do discurso figuram, junto com enunciação/enunciado concreto, interação verbal, arquitetônica e ato ético/estético a força-centro de todo o pensamento bakhtiniano porque, para o Círculo, nenhum sujeito fala no/para o "vazio" e nenhum enunciado é dito de qualquer modo. Como a comunicação discursiva é fundada, sobretudo, nas relações interlocutivas e elas moldam nosso projeto enunciativo-discursivo, os gêneros organizam aquilo que queremos dizer a partir de determinas esferas, algo maior que os gêneros, que, logo, organizam os atos humanos.

Gêneros do discurso e esfera da atividade perpassam quase todos os textos do Círculo. Segundo Brait e Pistori (2012, p. 397), a produtividade do conceito de gênero no pensamento bakhtiniano vai além da "fórmula mágica" composição, estilo e tema, assim lida por muitos, especialmente por aqueles que buscam "salvar" o ensino de leitura e produção de textos. O conjunto das obras do Círculo, afirmam as autoras,

aponta para a ideia de que os gêneros governam os discursos do dia a dia, interiores e exteriores, na medida em que os enunciados, os textos, são formulados segundo princípios genéricos. São, portanto, formas de pensar, constituindo um modo específico de visualizar 
e representar uma dada realidade, não se reduzindo a uma coleção de dispositivos nem a um modo de combinar elementos linguísticos.

Por uma questão de espaço, elenca-se, neste artigo, três dessas obras para discutir o tema do gênero no Círculo de Bakhtin: Problemas da poética de Dostoiévski (doravante PPD), publicada, pela primeira vez em 1929 com o nome Problemas da obra de Dostoiévski, e republicado em 1963, ampliado e alterado, com o novo título; no ensaio da década de 1950, o mais conhecido sobre o tema e que foi esboçado, porém não foi concluído, Os gêneros do discurso (doravante GD), publicado na coletânea póstuma Estética da Criação Verbal e recém traduzido numa versão isolada por Paulo Bezerra; e a obra de Pavel N. Medvedev O método formal nos estudos literários: uma introdução crítica a uma poética sociológica (doravante MFEL) da década de 1920.

Em PPD, Bakhtin (2013, p. 49) persegue as "[...] vozes diferentes, cantando diversamente o mesmo tema $[\ldots]^{\prime \prime}$ para comprovar a sua tese de que o romance dostoievskiano constitui-se em um gênero polifônico. Para isso, o autor levanta a historicidade do gênero recuperando aqueles que ele próprio chamou de gêneros carnavalizados. Com isso, além de mostrar a relação existente entre gênero literário sério-cômico, diálogo socrático e sátira menipeia, por exemplo, com folclore carnavalesco, esmiuçando particularidades desses dois gêneros, tratando dos gêneros intercalados (novelas, cartas, discursos oratórios, simpósios, etc.), demonstrando que os gêneros carnavalizados influenciaram a literatura e a cultura (BRAIT \& PISTORI, 2012), Bakhtin instituiu um conceito de extrema relevância para a compreensão do funcionamento dos gêneros do discurso: archaica. Esse conceito contribui para a observação do gênero não como um fenômeno novo, realizado sem uma relação com o passado, mas com marcas de generalidade (o que sempre existiu) e de singularidade (o vir a existir a partir das situações concretas de realização):

O gênero sempre conserva os elementos imorredouros da archaica. É verdade que nele essa archaica só se conserva graças à sua permanente renovação, vale dizer, graças à atualização. $\mathrm{O}$ gênero sempre é e não é o mesmo, sempre é novo e velho ao mesmo tempo. [...]. Nisso consiste a vida do gênero. Por isso, não é morta nem a archaica que se conserva no gênero; ela é eternamente viva, ou seja, é uma archaica com capacidade de renovar-se. O gênero vive do presente, mas sempre recorda o seu passado, o seu começo. (BAKHTIN, 2013, p. 121)

Nessa reflexão, Bakhtin (2013, p. 121) alerta que a organicidade do gênero pouco tem relação com a abstração tomada pelas linhas clássicas do formalismo e do estruturalismo como um todo: "[...] a lógica do gênero não é uma lógica abstrata. Cada variedade nova, cada nova obra de um gênero sempre a generaliza de algum modo, contribui para o aperfeiçoamento da linguagem do gênero". 
Aprofundando-se na dimensão não-abstrata das relações constitutivas do gênero que busca caracterizar, Bakhtin (2013, p. 207), no capítulo "O discurso em Dostoiévski", visa analisar o discurso, definindo-o como "a língua em sua integridade concreta e viva, e não a língua como objeto específico da linguística, obtido por meio de uma abstração absolutamente legítima e necessária de alguns aspectos da vida concreta do discurso", e lança a necessidade de criação de uma nova disciplina, Metalinguística, que tenha por objeto não apenas a forma composicional e suas particularidades léxico-sintáticas, as generalidades, mas foque, sobretudo, na realidade da linguagem, no discurso, quando há, para além das formas estruturais, a presença do extralinguístico, dos sujeitos, do contexto. Nesse prisma, Bakhtin (2013) propõe o estudo das relações dialógicas, algo que não pode, em hipótese alguma, ser encontrada na dimensão abstrata, per si , embora as envolva. "As relações dialógicas", afirma o autor,

são irredutíveis às relações lógicas ou concreto semânticas, que por si mesmas carecem de momento dialógico. Devem personificar-se na linguagem, tornar-se enunciados, converter-se em posições de diferentes sujeitos expressas na linguagem para que entre eles possam surgir relações dialógicas. (BAKHTIN, 2013, p. 209)

As relações dialógicas são, portanto, base fundadora para a concepção de gênero porque incorporam a dimensão composicional, mas não a toma como autônoma; considera a estilística, mas não a vê marcada, apenas, pela individualidade do autor; e, por fim, centra-se na temática, mas não a toma como o assunto. A palavra, o enunciado, para Bakhtin (2013, p. 228), é recheada de relações dialógicas porque é mobilizada por sujeitos de linguagem e é concreta, "[...] pode pertencer simultaneamente a diversas variedades e inclusive tipos". O gênero, enquanto tipos relativamente estáveis de enunciados, nessa visão, conforme aponta Machado (2008, p. 159), está inserido na cultura, "em relação à qual se manifesta como 'memória criativa' onde estão depositadas não só as grandes conquistas das civilizações, como também as descobertas significativas sobre os homens e suas ações no tempo".

Em um dos seus mais importantes ensaios sobre o tema, Os gêneros do discurso, de 1953-54, Bakhtin (2010) se propõe a caracterizar os gêneros tomando como ponto central a construção composicional, o estilo e o conteúdo temático e os define como "tipos relativamente estáveis de enunciado" (p. 262) que se organizam a partir de diferentes esferas da atividade humana que estão, por sua vez, ligados ao uso da linguagem. Segundo Lima (2014, p. 38), a concepção de estabilidade apresentada por Bakhtin se liga à ideia de repetição e diz respeito a algo que permanece inalterado ao longo do tempo. Entretanto, discute o autor, 
[...] no que diz respeito aos gêneros, essa inalteração é relativa, pois é sempre inalteração até certo ponto, nunca até o fim, havendo nisso espaço para a (re)criação. É justamente essa dinâmica contraditória existente entre repetição e (re) criação que interessa centralmente para pesquisas que se proponham a estudar gêneros do discurso, sendo indispensável que a investigação seja feita do ponto de vista das quatro dimensões indissolúveis constitutivas dos gêneros: 1) relação interlocutiva; 2) construção composicional; 3) conteúdo temático; 4) estilo.

O aspecto biopsicofisiológico do enunciado é apenas um, dos muitos, elementos de constituição dos gêneros. A individualidade do falante está presente e é algo constitutivo do enunciado e da produção dos gêneros do discurso. A essa individualidade, Bakhtin denominou estilo, afirmando que ele se revela nas diversas atividades de comunicação humana. Será a especificidade de cada campo de comunicação que vai determinar o gênero e, com isso, os estilos genérico e do autor: "o estilo integra a unidade do gênero do enunciado como seu elemento" (p. 266).

Na segunda parte do ensaio, Bakhtin (2013) faz, novamente, assim como em grande parte de seus escritos, um levantamento das definições dadas por autores em outras linhas de estudo da linguística para discorrer sobre a diferença entre enunciado e oração a fim de estabelecer um diálogo com eles. Contrapondo a perspectiva humbdoltiana, o autor apresenta, então, o ouvinte ${ }^{3}$ como sujeito ativo na comunicação discursiva:

[...] o ouvinte, ao perceber e compreender o significado (linguístico) do discurso, ocupa simultaneamente em relação a ele uma ativa posição responsiva: concorda ou discorda dele (total ou parcialmente), completa-o, aplica-o, prepara-se para usá-lo, etc.; essa posição responsiva do ouvinte se forma ao longo de todo o processo de audição e compreensão desde o seu início, às vezes literalmente a partir da primeira palavra do falante. (p. 271)

\section{E, com isso, introduz a questão da compreensão:}

Toda a compreensão da fala viva, do enunciado vivo é de natureza ativamente responsiva (embora o grau desse ativismo seja bastante diverso); toda a compreensão é prenhe de resposta, e nessa ou naquela forma a gera obrigatoriamente: o ouvinte se torna falante. A compreensão passiva do significado do discurso ouvido é apenas um momento abstrato da compreensão ativamente responsiva real e plena, que se atualiza na subsequente resposta em voz real alta. (p. 271)

A resposta do interlocutor para o enunciado do locutor não será, para Bakhtin, necessariamente verbal; a resposta é determinada por uma ação que também se configura no comportamento do indivíduo. Ao enunciar, o falante já pressupõe uma resposta do ouvinte, seja ela verbal ou não, pois tem internalizado que seu discurso,

3. Na recente tradução de Paulo Bezerra do ensaio "Os gêneros do discurso" (Editora 34, 2016), a expressão ouvinte é, por vezes, substituída por compreendedor. 
sua fala, seu enunciado afetará, de alguma forma, o outro que está em interação discursiva com ele:

É claro que nem sempre ocorre imediatamente a seguinte resposta em voz alta ao enunciado logo depois de pronunciado: a compreensão ativamente responsiva do ouvido (por exemplo, de uma ordem militar) pode realizar-se imediatamente na ação (o cumprimento da ordem ou comando entendidos e aceitos para execução), pode permanecer de quando em quando como compreensão responsiva silenciosa [...], mas isto, por assim dizer, é uma compreensão responsiva de efeito retardado: cedo ou tarde, o que foi ouvido e ativamente entendido responde nos discursos subsequentes ou no comportamento do ouvinte. (BAKHTIN, 2010b, p. 272)

Percebe-se, então, que o que está em jogo na definição bakhtiniana de gêneros do discurso são as relações interlocutivas "[...] que diz respeito ao modo constante mutável como o locutor e o interlocutor se veem e se tratam ao dialogar [...]" (LIMA, 2014, p. 38). São os sujeitos que possuem, independentemente da posição que assumem em uma interação, responsabilidade na formulação dos "tipos relativamente estáveis de enunciado". Composição, estilo e tema, nesse sentido, só podem ser vistos articulados aos posicionamentos sociais, históricos, institucionais, hierárquicos dos sujeitos da situação interacional que, por sua vez, estarão sempre atrelados a diferentes formas de agir no mundo, à diferentes esferas de atividades. Como as esferas de atividade são dinâmicas, no sentido de que elas incorporam novos modos de agir ressignificando a arte, a ciência e a vida (BAKHTIN, 2010), os gêneros também se transformam herdando o antigo, mas o inovando, o transformando. Concepção que também é trabalhada por Bakhtin em PPD, especialmente quanto à instabilidade e archaica dos gêneros quando é dito, lá, que o gênero não é velho e nem novo ao mesmo tempo. Todavia, Bakhtin (2010a), no ensaio dedicado apenas ao estudo dos gêneros do discurso, toma a riqueza e diversidade existente de gêneros como mote porque, também, são diferentes, inesgotáveis e multiformes os campos da atividade humana:

A vontade discursiva do falante se realiza antes de tudo na escolha de um certo gênero de discurso. Essa escolha é determinada pela especificidade de um dado campo da comunicação discursiva, por considerações semântico-objetais (temáticas), pela situação concreta da comunicação discursiva, pela composição pessoal de seus participantes, etc. A intenção discursiva do falante, com toda a sua individualidade e subjetividade, é em seguida aplicada e adaptada ao gênero escolhido, constitui-se e desenvolve-se em uma determinada forma de gênero. Tais gêneros existem antes de tudo em todos os gêneros mais multiformes da comunicação oral cotidiana, inclusive do gênero mais familiar e do mais íntimo". (p. 282)

Nesse sentido, gêneros do discurso e esferas da atividade, ou melhor, discurso e atividade são fatores indissociáveis (FAÏTA, 2002; BRAIT, 2002; MOURA-VIEIRA, 2012). Essa intrínseca e indissolúvel relação entre linguagem e 
atividade é explorada por Bakhtin (2010a, p. 266) na discussão, ainda no segundo bloco do ensaio, sobre a necessidade de diferenciar oração e enunciado, uma vez que o primeiro está na estrutura, não há sujeito, e o segundo, é quando a oração ganha vida, porque é mobilizada por sujeitos, em atos, que só o fazem no âmbito das esferas da atividade, a partir dos objetivos práticos e objetivos de comunicação:

\begin{abstract}
Uma determinada função (científica, técnica, publicística, oficial, cotidiana) e determinadas condições de comunicação discursiva, específicas de cada campo, geram determinados gêneros, isto é, determinados tipos de enunciados estilísticos, temáticos e composicionais relativamente estáveis. O estilo é indissociável de determinadas unidades temáticas e - o que é de especial importância - de determinadas unidades composicionais: de determinados tipos de construção do conjunto, de tipos do seu acabamento, de tipos de relação do falante com outros participantes da comunicação discursiva - com os ouvintes, os leitores, os parceiros, o discurso do outro, etc.
\end{abstract}

Nesse ensaio, o conceito de esfera de atividade figura anterior ao de gênero sendo, nesse sentido, seu "abrigo", pois todo gênero está alocado, e relacionado, a tipos específicos de atividade, isto é, o que existe aqui é uma "[...] impossibilidade de desvincular linguagem/atividades humanas, seja qual for a especificidade da atividade humana e a dimensão da linguagem aí envolvida [...]" (BRAIT, 2002, p. 31). Conforme aponta Sobral (2009, p. 121), no Círculo, as esferas de atividade são definidas como "regiões" de recorte sócio-histórico-ideológico do mundo, lugar das relações específicas entre sujeitos, e não só em termos de linguagem, "são dotadas de maior ou menor grau de estabilização a depender de seu grau de formalização, ou institucionalização, no âmbito da sociedade e da história, de acordo com conjunturas específicas". Para Grillo (2008, p. 147), o conceito de esferas da atividade em Bakhtin dá conta da realidade plural da atividade humana ao mesmo tempo que se assentam sobre o terreno comum da linguagem verbal e "é condicionadora do modo de apreensão e transmissão do discurso alheio, bem como da caracterização dos enunciados e de seus gêneros". Clot (2007, p. 45), por sua vez, salienta que "o gênero existe, de um lado, 'apreendido na ação' pessoal ou coletiva, e do outro, indexado a uma situação, enquanto meio de dotar de sentido essa ação fora daquela". Ou seja, a relação linguagem/atividade, atividade/linguagem é aspecto organizador e fundador dos gêneros do discurso.

E, por fim, na obra de Pavel M. Medviédev (2012, p. 193), O método formal nos estudos literários: uma introdução crítica a uma poética sociológica (MFEL), de 1928, a concepção de gênero é amplamente discutida em um debate intenso com os formalistas russos. Segundo o autor, os formalistas russos "definem o gênero como um agrupamento específico e constante de procedimentos com determinada dominante. Uma vez que os procedimentos fundamentais foram determinados fora do gênero, este foi 
mecanicamente composto a partir dos procedimentos". Medviédev (2012) conclui, então, que "o significado atual do gênero não foi compreendido pelos formalistas" e, tomando a poética como objeto, empreende uma importante discussão sobre o gênero artístico:

Entretanto, a poética deve partir precisamente do gênero. Pois o gênero é uma forma típica do todo da obra, de todo enunciado. Uma obra só se torna real quando toma a forma de determinado gênero. $O$ significado construtivo de cada elemento somente pode ser compreendido na relação com o gênero. (MEDVIÉDEV, 2012, p. 193)

Em MFEL, o gênero é apresentado como uma totalidade artística com dupla orientação: primeiro se orienta para os receptores, bem como para determinadas condições de realização e percepção. E, segundo, para a vida, por meio de seu conteúdo temático. "A seu modo, cada gênero está tematicamente orientado para a vida, para seus acontecimentos, problemas, e assim por diante" (MEDVIÉDEV, 2012, p. 195). Para Medviédev (2012), uma obra entra em um espaço real para ser lida de diferentes modos (em silêncio, em voz alta) e isso está, por sua vez, ligado às esferas de criação ideológica:

Ela pressupõe um ou outro auditório de receptores ou leitores, esta ou aquela reação deles, esta ou aquela relação entre eles e o autor. A obra ocupa certo lugar na existência, está ligada ou próxima a alguma esfera ideológica. [...]. Desse modo, a obra entra na vida e está em contato com os diferentes aspectos da realidade circundante mediante o processo de sua realização efetiva, como executada, ouvida, lida em determinado tempo, lugar e circunstâncias. Ela ocupa certo lugar, que é concedido pela vida, enquanto corpo sonoro real. Esse corpo está disposto entre as pessoas que estão organizadas de determinada forma. Essa orientação imediata da palavra como fato, mais exatamente como feito histórico na realidade circundante, determina toda a variedade de gêneros dramáticos, líricos e épicos. Cada gênero é capaz de dominar somente determinados aspectos da realidade, ele possui certos princípios de seleção, determinadas formas de visão e de compreensão a realidade, certos graus na extensão de sua apreensão e na profundidade de penetração nela (Idem, p 195-6).

\section{Para Brait e Pistori (2012, p. 385), a concepção de gênero em MFEL}

demonstra, criteriosa e detalhadamente, que gênero é o conjunto dos modos de orientação coletiva dentro da realidade, encaminhado para a conclusão de que, por meio do gênero, é possível compreender novos aspectos da realidade, ou, em outras palavras, a realidade do gênero é a realidade social de sua realização no processo da comunicação, ligados de forma estreita ao pensar.

A concepção de gênero pode ser encontrada, ainda, em outras obras do Círculo $^{4}$ e contribui diretamente com a reflexão e com a prática da tradução e da

4. Para ver mais detalhes sobre a concepção de gêneros do discurso em todas as obras do Círculo, conferir Brait e Pistori (2012). 
interpretação por nos permitir observar o trabalho de quem as realiza não como ações limitadas à análise da dimensão textual, estrutural e formal apenas, mas, sobretudo, como atividades de mobilização discursiva de enunciados concretos produzidos por sujeitos inscritos em diferentes comunidades, culturas e esferas. A tradução e a interpretação, nesse sentido, são "práticas discursivas de dimensão enunciativa, interativas e mediadoras de atos comunicativos" (NASCIMENTO, 2016, p. 130), cada uma em sua especificidade cronotópica e operacional, porque constroem a ponte interacional "quebrada" - ou não construída - pela incompreensão ou pelo desconhecimento dos sistemas semióticos-ideológicos dos respectivos interactantes. Como práticas de dimensão enunciativa, que são marcadas por actorialidade, temporalidade e espacialidade (FIORIN, 2016), e discursiva, porque mobilizam as línguas em situações concretas e reais, essas atividades promovem o endereçamento de enunciados produzidos em determinados contextos por meio da mediação. Esses enunciados, por sua vez, possuem suas formas relativamente estáveis constituídas de generalidades e singularidades.

Do ponto de vista sócio-histórico, a tradução vem mobilizando textos e discursos de dimensão verbal a fim de promover o intercâmbio entre homens, culturas e comunidades. Segundo Oustinoff (2011), a tradução possui três principais aspectos: o primeiro, de ordem prática, é o caráter comunicativo, "sem ela, a comunicação fica comprometida ou se torna impossível" (p. 12). A segunda, diz respeito à compreensão das línguas envolvidas, ou seja, "não é a mesma coisa traduzir do hebraico, língua camito-semítica, para o grego, língua indo-europeia" (p. 13). Há que se considerar as especificidades das línguas a serem traduzidas para garantir que a comunicação entre as diferentes comunidades seja estabelecida. E embora a função comunicativa da tradução e sua dimensão linguística sejam importantes para compreender essa atividade, elas não são suficientes. Por isso Outinoff (2011) apresenta, então, o terceiro aspecto, que é a condição plural das versões de um mesmo texto. Pode haver tantas compreensões possíveis quanto versões tornando o texto fonte, então, uma fonte de produção de sentidos. Bezerra (2015, p. 236) compreende que a tradução pode ser abordada como uma espécie de arte e que, nessa visão, "é produto de uma subjetividade especial, que, mesmo traduzindo obra alheia, procura dar vida própria na língua de chegada, fazendo do original uma obra independente numa outra língua, numa outra cultura, dando-lhe uma nova existência histórica". Não foi à toa que o escritor José Saramago disse que "são os autores que fazem as literaturas nacionais, mas são os tradutores que fazem a literatura universal".

Todavia, embora a tradução mobilize exponencialmente textos verbais, o linguista russo Roman Jakobson atentou, na década de 1950, que a tradução poderia, 
também, ser realizada entre diferentes materialidades. Segundo o autor existem três tipos de tradução:

\begin{abstract}
tradução intralingual, reformulação (rewor-ding) consiste na interpretação dos signos verbais por meio de outros signos da mesma língua (ii) tradução interlingual, ou tradução propriamente dita consiste na interpretação dos signos verbais por meio de alguma outra língua; e (iii) A tradução inter-semiótica ou transmutação consiste na interpretação dos signos verbais por meio de sistemas de signos não-verbais. (JAKOBSON, 2010, p. 43)
\end{abstract}

No caso das línguas de sinais, o primeiro aspecto a ser considerado é que, do ponto de vista interlingual, a tradução mobiliza línguas de modalidades diferentes: línguas orais-auditivas, em que a recepção das informações é realizada pela audição e produzida pelo aparelho fonador, e línguas gesto-visuais, em que a recepção é realizada pela visão e a produção pelas mãos e corpo (QUADROS, 2006; RODRIGUES, 2013). Essa especificidade no processo tradutório possui efeitos diretos na atuação de tradutores e de intérpretes que trabalham com essas línguas porque, além de uma tradução interlíngue de caráter intermodal (SEGALA, 2010), a tradução pode ser também intersemiótica por promover transformação das visualidades extralinguísticas ${ }^{5}$ constitutivas de alguns textos fontes, sobretudo os que possuem características verbo-visuais, em materialidade linguística. Por essa razão, Segala (2010) propôs a tradução intermodal como uma quarta modalidade de tradução, a fim de abranger as especificidades das línguas de sinais. A proposta, na verdade, conforme destacam Quadros e Segala (2010, p. 358), "capta a especificidade dos aspectos na tradução intralingual, tradução interlingual e intersemiótica que inclui uma língua de sinais. Ou seja, a tradução intermodal está imersa nesses três diferentes tipos de tradução identificados por Jakobson"

Como prática discursiva que mobiliza enunciados intermodais a partir de gêneros discursivos diversos, o processo tradutório de línguas de sinais demanda análise apurada de aspectos visuais do texto fonte, fator que ...... difere um pouco de processos tradutórios monomodais, especialmente quando o par linguístico é composto por línguas de modalidade oral-auditiva ${ }^{6}$. No caso de traduções intermodais, o texto fonte pode envolver uma espécie de verbo-visualidade, ou seja,

5. A expressão "extralinguística" aqui será usada para estabelecer distinção entre a dimensão verbal definida, sobretudo, na Linguística Moderna. No pensamento bakhtiniano, o termo é invocado sempre que o debate lança luz sobre os aspectos situacionais, contextuais em relação à dimensão sistêmica, abstrata da língua.

6. Destacamos, nesse caso, as de modalidade oral-auditiva porque com a ocasião do uso da internet e do intercâmbio entre as diferentes comunidades surdas mundiais, traduções (e interpretações) monomodais entre línguas de sinais tem acontecido com frequência. Pode-se traduzir (e interpretar), por exemplo, um texto produzido em American Sign Language (ASL - Língua Americana de Sinais) para Libras. 
quando há "[...] um enunciado concreto articulado por um projeto discursivo do qual participam, com a mesma força e importância, a linguagem verbal e a linguagem visual" (BRAIT, 2010, p. 194).

Esses aspectos ganham destaque quando a prática de tradução ocorre em esferas e gêneros em que a verbo-visualidade é constitutiva dos enunciados e da produção de sentidos como, por exemplo, as esferas que possuem diferentes mídias audiovisuais como suportes de circulação. Enquanto a tradução monomodal entre línguas orais-auditivas preocupa-se com a dimensão verbal e dá à dimensão visual extralinguística um caráter mais descritivo, a tradução intermodal traduz intersemioticamente essa visualidade pelas características materiais da língua de sinais. Este fenômeno ocorre porque

\begin{abstract}
o verbal também é visual, tal como a linguagem escrita é. No entanto, a visualidade da língua de sinais possui sua especificidade por ser, além do visual, gestual. Na produção verbal, portanto, em um ato de interpretação [tradução], há grandes riscos de existir concorrência, do ponto de vista do todo do enunciado, entre esse verbal-visual com o visual constituinte dos elementos extralinguísticos. Eis então a necessidade de abordar a [tradução e a] interpretação da língua de sinais a partir da totalidade verbo-visual do enunciado concreto para que os efeitos de sentido do discurso fonte alcancem o interlocutor por meio do processo de interpretação [e de tradução]. (NASCIMENTO, 2014, p. 220)
\end{abstract}

Nesse sentido, para discutir a tradução de língua de sinais em materiais audiovisuais é necessário ampliar a reflexão e deslocar-se da concepção de que a janela de Libras é mais um recurso de acessibilidade para pessoas que não podem acessar o conteúdo oral por impossibilidades sensoriais auditivas. É preciso debater a captação do tradutor, a edição de sua imagem e a inserção da janela como acabamento específico dos enunciados produzidos em determinados gêneros do discurso e a tradução como criação de novos enunciados (BEZERRA, 2015). Defenderemos, portanto, que a janela de Libras deve ser inserida de modo a compor a totalidade da produção audiovisual a partir das suas peculiaridades genéricas e discursivas.

\title{
2. CONTEXTO DE COLETA DO CORPUS
}

O corpus foi colhido em um curso de especialização em Tradução/Interpretação de Libras/Português de uma instituição de educação superior privada na cidade de São Paulo. Esse curso tem como objetivo aperfeiçoar e formar tradutores e intérpretes que possuem outras formações de base, mas que atuam com a tradução e com a interpretação do par Libras/LP. Tendo em vista o deslocamento sócio-histórico de TILS das esferas religiosas, familiares e comunitárias para as esferas profissionais, muitos trabalhadores do campo possuem formação em áreas diversas como Letras, 
Pedagogia, Fonoaudiologia, Educação Especial, Administração, Enfermagem dentre outras (NASCIMENTO, 2016; MARTINS \& NASCIMENTO, 2015). Em alguns casos, essas formações, principalmente as relacionadas às humanidades, foram motivadas pela relação e convivência com as pessoas surdas. Entretanto, muitos desses sujeitos redirecionaram as carreiras para atuar no campo da tradução e da interpretação de língua de sinais sendo necessária, portanto, uma nova formação.

Todavia, há que se destacar que a formação em nível superior para TILS no Brasil é extremamente recente. O primeiro curso de graduação em tradução e interpretação em Libras/LP foi ofertado pela primeira vez em 2008 pela Universidade Federal de Santa Catarina (UFSC) na modalidade a distância e formou aproximadamente 400 novos profissionais (QUADROS \& STUMPF, 2015). Após a finalização das primeiras turmas, a UFSC passou a oferecer o curso na modalidade presencial e restringiu a modalidade a distância para alguns estados. Em 2011, com o Plano Viver Sem Limites do governo federal (BRASIL, 2011), oito novos cursos de Bacharelado foram abertos em todo o país expandindo a oferta da formação em nível superior para outras universidades. Entretanto, oito cursos é ainda um número ínfimo de espaços formativos em nível de graduação frente à demanda de novos profissionais.

Nesse sentido, a legislação tem proposto espaços formativos alternativos para tradutores e intérpretes de Libras e LP como, por exemplo, conforme determina o Decreto 5.626/05, cursos de formação profissional e continuada. O curso em que o corpus foi colhido se propõe como um espaço de formação continuada em nível de pós-graduação lato sensu. Com uma carga horária de 450 horas, o curso em tela propõe uma formação generalista visando suprir a ausência de uma primeira formação no campo da tradução e da interpretação para quem já atua na área e, também, abordar a realidade plural dos espaços em que o TILS tem atuado. Por essa razão, a grade curricular do curso é composta por disciplinas de tradução e disciplinas de interpretação que são discutidas a partir de diferentes gêneros e esferas ${ }^{7}$. Dentre as disciplinas ofertadas, tradução e interpretação na esfera midiática compõe o eixo focado nas práticas tradutórias e interpretativas com o objetivo de debater e colocar o aluno na posição de tradutor de materiais audiovisuais. A disciplina possui 20 horas sendo 16 delas presenciais e 4 horas são realizadas por meio de atividades supervisionadas a distância. As aulas acontecem uma vez por mês no sábado e no

7. Nossa pesquisa de doutorado versou sobre a realidade dos cursos de formação de tradutores e de intérpretes de Libras/LP e discutiu detalhadamente o curso de especialização em que o corpus analisado aqui foi coletado. (Cf. NASCIMENTO, 2016). 
domingo (8 horas por dia) sendo módulos intensivos de reflexão e de prática de tradução e de interpretação.

A disciplina tradução e interpretação na esfera midiática, de caráter teórico-prático, aborda os seguintes pontos: (i) perspectiva bakhtiniana de linguagem, gênero, esfera, discurso e seus desdobramentos para a tradução; (ii) pluralidade midiática na circulação de gêneros; (iii) exploração dos gêneros que circulam em vídeo; (iv) marcas de verbo-visualidade dos gêneros que circulam em vídeo; (v) análise da verbo-visualidade para os processos tradutórios; (vi) discussão sobre os lugares da janela de libras; (vii) execução da tradução e edição; (viii) esferas de recepção e circulação do produto traduzido. Esses pontos são organizados didaticamente em quatro partes por meio de aula expositiva, análise de materialidade do texto-fonte, execução da tradução e discussão coletiva sobre o produto traduzido, conforme demonstração abaixo:

Quadro 1. divisão e execução didática da disciplina

\begin{tabular}{|l|ll|}
\hline $\begin{array}{l}\text { PARTE I } \\
\text { Aula expositiva }\end{array}$ & (i) & $\begin{array}{l}\text { perspectiva bakhtiniana de linguagem, gênero, esfera, discurso } \\
\text { e seus desdobramentos para a tradução; } \\
\text { pluralidade midiática na circulação de gêneros; }\end{array}$ \\
\hline $\begin{array}{l}\text { PARTE II } \\
\text { Análise de materialidade } \\
\text { do texto-fonte }\end{array}$ & $\begin{array}{l}\text { (iii) } \\
\text { (iv) }\end{array}$ & $\begin{array}{l}\text { exploração dos gêneros que circulam em vídeo; } \\
\text { marcas de verbo-visualidade dos gêneros que circulam em } \\
\text { vídeo; } \\
\text { análise da verbo-visualidade para os processos tradutórios; }\end{array}$ \\
\hline $\begin{array}{l}\text { PARTE III } \\
\text { Execução da tradução }\end{array}$ & (vi) & $\begin{array}{l}\text { discussão sobre os lugares da janela de libras; } \\
\text { execução da tradução e edição; }\end{array}$ \\
\hline $\begin{array}{l}\text { PARTE IV } \\
\text { Discussão coletiva sobre o } \\
\text { produto traduzido }\end{array}$ & (viii) & esferas de recepção e circulação do produto traduzido; \\
\hline
\end{tabular}

Fonte: desenvolvido pelo autor.

A organização didática da disciplina em partes leva em consideração cinco passos didáticos para a formação de tradutores envolvendo a aprendizagem de tradução intermodal a partir da perspectiva bakhtiniana:

(i) Mobilizar os intérpretes/tradutores em formação à reflexão, por meio da leitura sobre as relações de intergenericidade presentes durante o processo de interpretação contrapondo diferentes gêneros e, com isso, fazendo com que eles, enquanto sujeitos/autores, observem a totalidade dos enunciados tornando-se capazes de diferenciar as marcas e especificidades de cada um;

(ii) Explorar cada gênero a ser trabalhado visando a identificação de aspectos visuais que não precisam ser traduzidos para a língua de sinais, justamente pela 
possibilidade de competição visual entre o verbal e o visual,

(iii) Mapear elementos visuais constituintes da totalidade do discurso fonte que podem/devem ser absorvidos pela tradução/interpretação a fim de que o discurso verbal case com o visual formando, portanto, uma totalidade de sentido contribuindo para um efeito único, do ponto de vista do todo do enunciado, para o interlocutor surdo,

(iv) Preparar a tradução/interpretação considerando o todo do enunciado concreto elaborando, desse ponto de vista, uma competência referencial sobre o gênero a ser interpretado.

(v) Traduzir/Interpretar considerando as especificidades mapeadas e exploradas buscando produzir um enunciado que contemple a dimensão visual dos elementos extralinguísticos que compõem o discurso fonte a ser transposto (NASCIMENTO, 2014, p. 221).

Diante disso, na parte I do curso, discute-se teoricamente como os conceitos bakhtinianos podem contribuir com uma prática tradutória que leva em consideração as dimensões verbais e extraverbais e, no caso das línguas de sinais, como a tradução intermodal pode ser mobilizada a partir dessa reflexão. Com base nesse direcionamento teórico, levantam-se os gêneros discursivos possíveis de circular em vídeo e quais as especificidades de cada um. Na parte II, os estudantes exploram os gêneros mapeados a partir das marcas de verbo-visualidade. Na parte III, debatem sobre quais as possibilidades de inserção da janela de Libras nos gêneros trabalhados. Para isso, exploram a norma da ABNT 15.290 e buscam adaptá-la à realidade discursiva do vídeo que será mobilizado em tradução. E na parte IV realizam a tradução em grupo discutindo as escolhas e estratégias de incorporação (ou não) da verbo-visualidade na língua de sinais editando, na sequência, com o software gratuito VSDC Free Vídeo Editor, o vídeo fonte junto com a janela de Libras. Após o mapeamento prévio do vídeo e a execução da tradução, os tradutores do grupo narram, individualmente pela escrita e pela oralidade, para o coletivo as motivações, argumentos e explicações da janela utilizada.

A discussão sobre a janela de libras e sobre as práticas de tradução envolvendo línguas de sinais em produções audiovisuais de uma perspectiva bakhtiniana, com foco nos conceitos de enunciado concreto, gêneros do discurso e esferas da atividade, gera efeitos diretos para a prática tradutória e, sobretudo, para a formação dos tradutores. Nesse sentido, mostraremos, a seguir, como os tradutores de língua de sinais em formação produziram, no curso em questão, janelas de Libras de dois gêneros distintos a partir da reflexão sobre este recurso como unidade específica no acabamento do enunciado. Utilizaremos recortes das imagens dos 
vídeos e depoimentos escritos de grupos de duas turmas do curso. Os participantes assinaram um termo de autorização para o uso de suas produções nessa publicação.

\section{TRADUÇÃO, JANELAS DE LIBRAS E FORMAÇÃO: ACABAMENTO A PARTIR DA DUPLA ORIENTAÇÃO DO GÊNERO}

$\mathrm{Na}$ parte II da disciplina, os estudantes mapeiam, em grupo, diferentes gêneros que podem circular no formato vídeo identificando os aspectos linguísticos e extralinguísticos para a tradução. Na tentativa de oferecer aos estudantes pluralidade das possibilidades tradutórias a partir desse levantamento coletivo, pede-se que eles se dividam em quatro grupos de trabalho para realizar a análise e mapeamento do texto fonte focando diferentes aspectos do gênero descritos por Bakhtin (2010). Cada grupo fica responsável por analisar e traduzir um gênero específico sendo, portanto, quatro gêneros trabalhados no contexto formativo: jornalismo televisivo, revista eletrônica, videoaula e contação de histórias. Neste artigo, mostraremos o produto final dos dois últimos gêneros. Todos os vídeos utilizados como texto fonte são retirados na plataforma de vídeos YouTube e são de domínio público.

O primeiro gênero a ser analisado é videoaula. Segundo Camargo, Garofalo e Coura-Sobrinho (2011, p. 83)

a videoaula é um gênero que claramente absorve características da aula presencial, como a existência de um enunciado expositivo, planejado e muitas vezes apresentado por um professor, com a intenção de levar conhecimento ao aluno em um processo de ensino-aprendizagem. Entretanto, ele traz novas características, como a utilização da mídia audiovisual, a interação assíncrona ou ausência de interação com os alunos, a possível utilização simultânea de várias linguagens visuais que podem ser combinadas com o áudio, etc.

Esse é um gênero, portanto, que corresponde a uma variação do gênero aula, com circulação recorrente na esfera acadêmico-escolar, que "devido à necessidade de práticas sociais que não vinculem as pessoas a lugares físicos e momentos síncronos, inclusive instituições de ensino" (CAMARGO, GAROFALO, COURA-SOBRINHO, 2011, p. 83) tem se deslocado para novas formas de produção, recepção e circulação. $\mathrm{O}$ gênero possui como objetivo central colocar o telespectador na posição de aprendiz dos conteúdos a serem transmitidos e, por isso, a discussão sobre o tamanho e a posição da janela de Libras realizada pelos grupos levou em consideração o fato de que o público surdo, enquanto possível interlocutor do conteúdo de aula, precisa acessar os conteúdos da aula do mesmo modo que um aluno ouvinte acessa. 


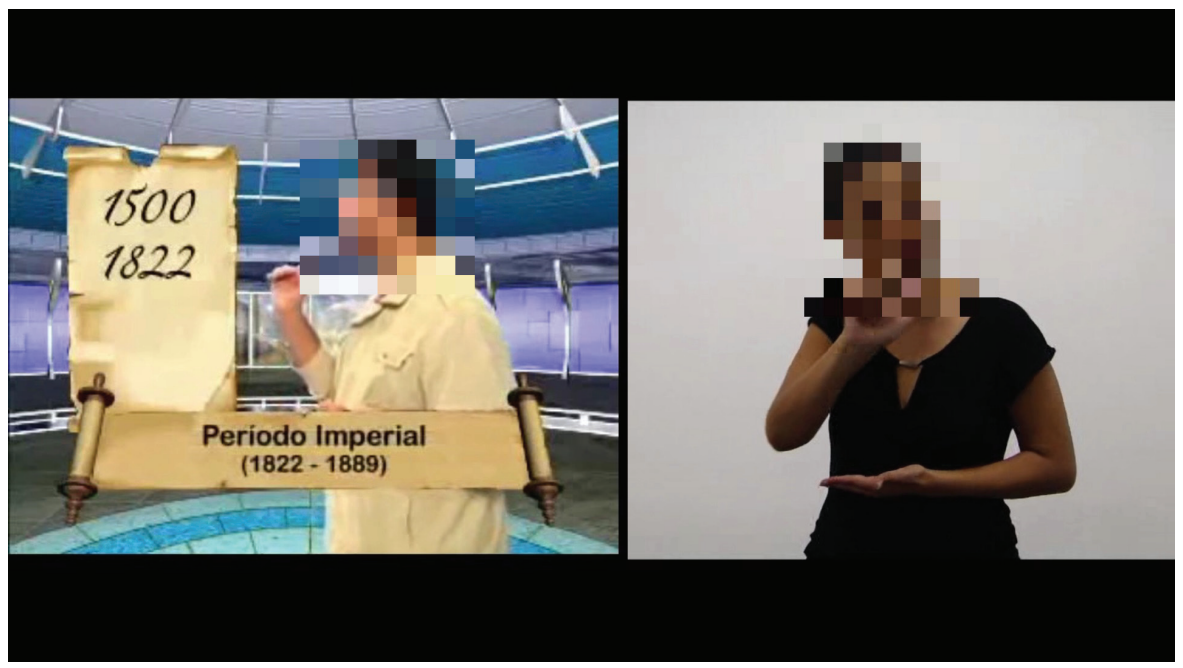

Figura 1. janela de Libras do gênero videoaula proposta pela primeira turma. Fonte: desenvolvido pelos estudantes do curso.

Na figura 1, mostra-se a opção do primeiro grupo por uma janela do mesmo tamanho do vídeo fonte da tradução. A edição, então, colocou o vídeo que foi gravado pelos estudantes no tamanho equivalente ao da videoaula, sendo necessária a diminuição do vídeo fonte e do vídeo em Libras para que ambas tivessem o mesmo tamanho. Essa decisão fez com que o tradutor ficasse na mesma posição e altura do professor, o que poderia provocar no aluno surdo uma sensação de pertencimento. Essa decisão, também, possibilitou ao grupo sincronizar as informações verbovisuais e extralinguísticas acrescidas durante a videoaula direcionando a visão do espectador para o vídeo, quando necessário, por meio de apontações laterais especialmente quando a informação verbo-visual, no vídeo, competir com a língua de sinais. A tradutora em formação que aparece no recorte acima justificou a escolha de seu grupo com o seguinte depoimento:

\begin{tabular}{|c|}
\hline A escollha da janela se deu por conta de que o vídeo traduzido trazia muitas informações visuais e \\
tendo a janela de Libras sobreposta ao mesmo, algum dado importante poderia ser ocultado ou ainda \\
causar estranbamento ao espectador, devido as várias informações que aparecem na tela, mais a \\
sobreposição da janela de Libras. Então, escolbemos deixar as telas separadas, para que bouvesse \\
clareza e maior organização duando alguém se utilizasse da tradução do vídeo. \\
Depoimento grupo videoaula - turma 1
\end{tabular}

Bakhtin/Volochínov (2009) destaca que todo enunciado é direcionado para um auditório social real e discursivo, ou seja, "mesmo que não haja um interlocutor 
real, este pode ser substituído pelo representante médio do grupo social ao qual pertence o locutor" (p. 116). Nesse sentido, o aluno surdo, enquanto sujeito posicionado como aprendiz na esfera em questão, no caso acadêmica, poderia participar da videoaula acessando o conteúdo com clareza e conforto e não com um esforço para buscar o conteúdo que precisa aprender em um espaço pequeno na lateral inferior, formato comum nas janelas de Libras. O aluno surdo vê, diante de si, a sua língua sendo colocada no mesmo patamar de importância e valor que a do professor. Em um contexto sócio-histórico em que as línguas de sinais sempre foram vistas como inferiores em relação às línguas orais, tê-la projetada no mesmo tamanho e importância que a LP pode ter efeitos, inclusive, na forma como esse aluno se relacionará com o conteúdo da aula. Se "o mundo interior e a reflexão de cada indivíduo têm um auditório social próprio bem estabelecido, em cuja atmosfera se constroem suas deduções interiores, suas motivações, apreciações, etc." (BAKHTIN/VOLOCHÍNOV, 2009, p. 117), os tradutores do primeiro grupo optaram por valorizar esse auditório social salientando a importância do interlocutor surdo como aprendiz e de sua língua por meio da projeção da janela no mesmo tamanho que a do vídeo. Em uma rápida busca nas plataformas virtuais que exibem vídeos e nos sites de busca na internet, pode-se observar que essa proposta parece ainda longe do real, mas pode ser uma opção quando a instituição de ensino superior ofertante de videoaulas optar por dar mais que acessibilidade para o aluno surdo, mas querer fazê-lo participante de fato do conteúdo ministrado.

O grupo da turma 2 optou por uma janela um tanto quanto diferente que a do grupo supra descrito, conforme pode-se perceber na figura 2:

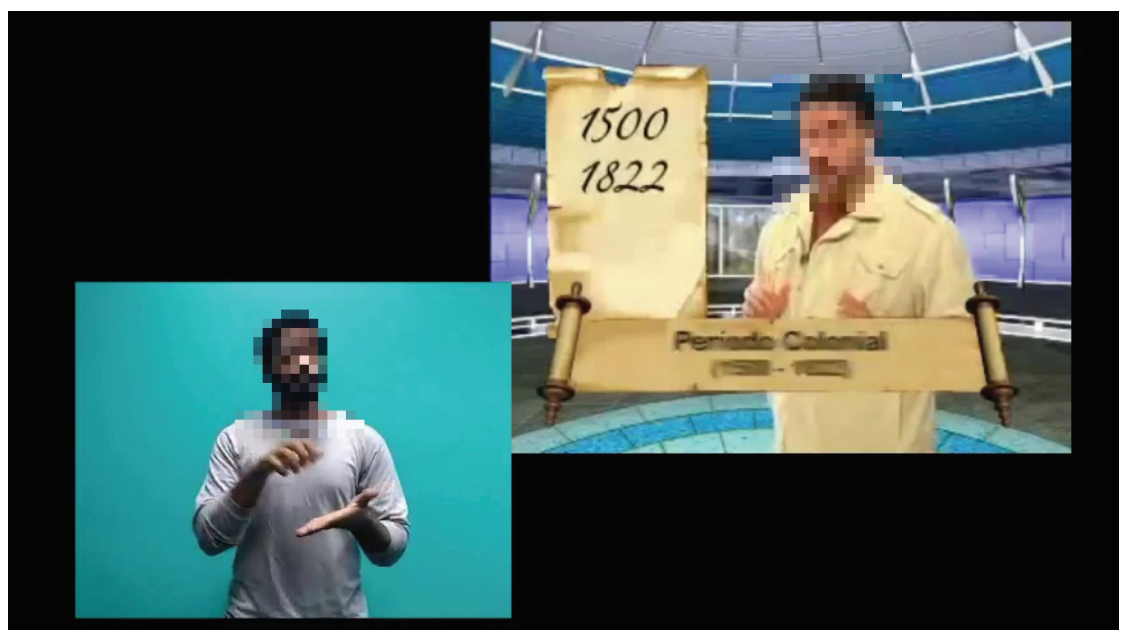

Figura 2. janela de Libras do gênero videoaula proposta pela segunda turma.

Fonte: desenvolvido pelos estudantes do curso. 
Neste caso, embora a janela não esteja do mesmo tamanho que a do professor, pode-se notar que houve uma preocupação de isolar o espaço do tradutor do vídeo fonte a fim de propiciar que as informações exibidas no vídeo pudessem ser totalmente compreensíveis pelo aluno surdo. É possível, também, visualizar com clareza a imagem do tradutor, bem como suas mãos. Essa opção de janela também possibilita, do ponto de vista tradutório, o uso de apontações laterais superiores para a tela do vídeo fazendo com que o aluno visualize as informações verbo-visuais ao mesmo tempo que vê a tradução da língua de sinais. Percebe-se, ainda, que a cor do fundo da janela está em contraste com a roupa e com o tom de pele do tradutor conforme preconiza a NBR 15.290 da ABNT. Um outro aspecto a ser acentuado neste modelo é a localização da janela à esquerda do vídeo. Tendo em vista que comumente a leitura nas sociedades ocidentais inicia pelo lado esquerdo, o posicionamento da janela à esquerda pode ser mais confortável para a visualização da língua de sinais e para a absorção das informações visuais do vídeo. Evidente que essa hipótese é passível de investigação, mas esse seria um estudo interessante para observar a usabilidade da localização das janelas de Libras pelos usuários surdos. No depoimento, o tradutor da imagem acima destacou as discussões realizadas em seu grupo:

\begin{tabular}{|} 
Para a escolba do tamanho da janela, foi levado em consideração a participação integral do surdo \\
na aula, e que isso fosse de "igual para igual" (ouvintes e surdos). Como grupo acreditamos que \\
com esse tamanho da janela, o aluno surdo poderia aproveitar mais os recursos visuais (fotos e \\
linba do tempo) que a aula continha. Em relação a posição janela, foi pensado no tempo que o \\
aluno faria o desvio do olhar, e como a janela já está em um tamanho maior e posicionada de forma \\
que o aluno não perca tempo desviando o olhar, acredito que o aluno se sentiria "parte da aula". \\
Depoimento grupo videoaula - turma 2 \\
\hline
\end{tabular}

Embora a opção do tamanho da janela em ambos os grupos tenha sido diferente, percebe-se, pelos depoimentos, que uma das preocupações dos estudantes foi colocar o possível aluno surdo dessas videoaulas em posição qualificada de aprendiz e de propiciar, então, uma sensação, pela visualização da janela, de pertencimento ao que estava sendo enunciado. Para Bakhtin (2010, p. 272), o interlocutor do discurso ocupa uma posição responsiva concordando, discordando, assentindo com o enunciado que está recebendo, "toda compreensão plena real é ativamente responsiva e não é senão uma fase inicial preparatória da resposta (seja qual for a forma em que ela se dê)". Ao se preocupar não apenas com as formas de captação da imagem do tradutor, mas com a edição da janela a partir das especificidades e orientação externa desse gênero, ou seja, com a esfera de recepção e de circulação, 
os tradutores em formação exploraram a ideia de que a informação precisaria estar apenas acessível, isto é, receptível aos surdos usuários de Libras, mas foram além pensando na janela de Libras como aspecto constitutivo da aprendizagem desse aluno.

Observemos, a seguir, o outro gênero trabalhado no curso: contação de histórias. Para Arboleya e Bringmann (2008, p. 3), a contação de histórias hoje em dia não é apenas um recurso cultural divulgado por grupos da cultura popular, mas "é também uma atividade pedagógica que não se caracteriza apenas pela habilidade artística e comunicacional de quem conta, mas também de se inserir no contexto de uma cultura letrada, que se apropria da escrita como meio instigador e registrador da história". Os autores ainda destacam que o conto narrado pode funcionar como estímulo para o estudo de diferentes áreas do saber, para o desenvolvimento de habilidades cognitivas e, sobretudo, para o endossamento da diversidade cultural através da narrativa histórica que apresenta à criança a oportunidade de conhecer um dado povo ou cultura através do olhar poético que o escritor (e o contador) lança sobre a realidade desse povo.

No que diz respeito à circulação desse gênero em língua de sinais, a contação de histórias compõe a chamada cultura surda, sintagma que, conforme defende Felício (2013), causa desconforto em alguns e sensação de pertencimento em outros. Como comunidade constituída por experiência sensoriais visuais e traços linguísticos e culturais distintos dos ouvintes, os surdos vêm produzindo o que eles próprios chamam de literatura surda. Segundo Rosa (2006, p. 59), "como o surdo utiliza a visão para obter informações, a união da mídia e da literatura cria condições para que haja um fortalecimento da identidade, cultura e de conhecimento da surdez". As narrativas "orais" ${ }^{18}$ em língua de sinais circulam na comunidade surda de forma a afirmar esses traços culturais e identitários. Felício (2013, p. 39) destaca que

tinha-se a ideia de que contar histórias de forma artística e poética somente era possível nas línguas orais, porém, o povo surdo, ao apropriar-se das obras escritas, passou a realizar traduções para língua de sinais, possibilitando acesso ao conteúdo literário em seu formato visual e espacial, bem como um registro mais sistematizado das obras criadas em língua de sinais. Surgem talentosos contadores de histórias surdos, que com suas mãos e corpo fazem o contorno dos significantes e seus significados, proporcionando ao povo surdo acesso a emoções antes destinadas somente aos auditivos na língua oral, que são a partir de então

8. Usa-se o termo "oral", aqui, para salientar que as narrativas em língua de sinais carecem, ainda, de registros para a circulação. Embora a tecnologia tenha sido um ganho para as comunidades surdas, o registro e replicação é uma prática ainda em construção entre os usuários da língua de sinais. As aspas, nesse caso, indicam a ausência de um termo mais adequado para esse contexto e porque este termo, também, carrega carga semântica ligada à concepção saussureana de que a produção linguística é realizada, apenas, pelo aparelho fonador. 
reveladas através do canal visual. Aos auditivos, é proporcionada a beleza da língua de sinais, atravessando as barreiras do "mundo de silêncio" e adentrando ao "universo surdo".

Nesse sentido, uma tradução de contação de histórias para a língua de sinais deve levar em consideração as características visuais, culturais e linguísticas de recepção de informações desse público-alvo como aspectos orientadores do gênero. Vejamos, na sequência, a proposta e solução de janela de Libras do primeiro grupo para tentar alcançar as especificidades da comunidade surda enquanto espectadora de contação de histórias.

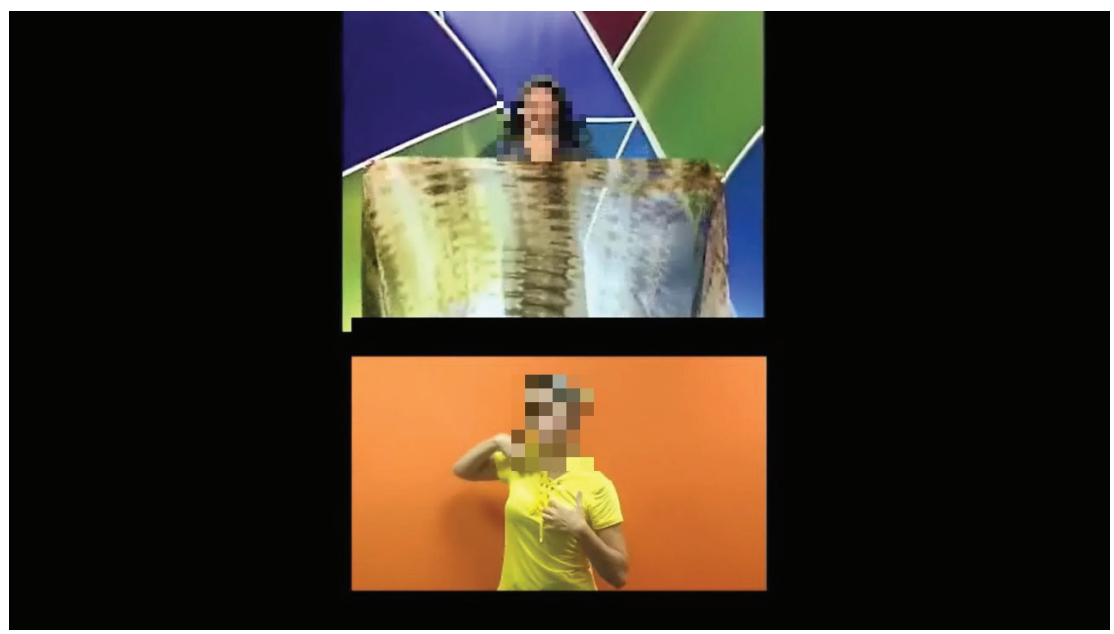

Figura 3. janela de Libras do gênero contação de histórias proposta pela segunda turma. Fonte: desenvolvido pelos estudantes do curso ${ }^{9}$.

$\mathrm{Na}$ proposta acima, a janela foi colocada na parte inferior e o vídeo fonte foi colocado na parte superior. $\mathrm{O}$ argumento para essa escolha pode ser lido, com detalhes, no depoimento escrito realizado pela tradutora do grupo que está na imagem acima:

9. Contação de histórias disponível em: https://www.youtube.com/watch?v=pxVcpHYD3D4 
A escolba do tamanbo da janela de Libras foi pensada com base no público que queríamos atingir, no caso como o vídeo era uma contação de bistória optamos por uma janela maior, pois o público alvo seriam crianças e como o público infantil é difícil se manter atento assistindo com uma janela com o tamanbo patrão da ABNT NBR 15290, decidimos optar por uma janela de libras maior. Em relação ao posicionamento da janela, optamos por dividir a tela deixando em cima o vídeo e em baixo a janela de Libras, as duas imagens tendo o mesmo tamanbo. Decidimos dividir na borizontal os dois vídeos, pois acreditamos ser mais confortável para quem estiver assistindo, pois os olbos sempre busca (sic) a imagem que está em cima e automaticamente olba a imagem que está a baixo conseguindo acompanbar os dois vídeos simultaneamente.

Depoimento grupo contação de histórias - turma 2

O critério principal utilizado pelo grupo, de acordo com o depoimento, para o uso dessa janela foi a característica central do público-alvo, no caso, crianças surdas. Na dupla orientação do gênero artístico apontada por Medviédev (2012, p. 195), os interlocutores de um enunciado, de uma obra, encontram-se em primeiro plano, isto é, são os principais determinantes para sua produção: "entra em um espaço e tempo real: para ser lida em voz alta ou em silêncio, ligada à igreja, ao palco ou ao teatro de variedades [...]. Ela pressupõe um ou outro auditório de receptores ou leitores, esta ou aquela reação deles, esta ou aquela relação entre eles e o autor". No caso da proposta acima, a construção enunciativa em língua de sinais na janela de Libras preocupou-se com a visualização do discurso em Libras e a sincronização destes enunciados com o vídeo fonte. Por ser a contação de histórias um gênero marcado por intensificação e variação da prosódia, pela caracterização do contador (em alguns casos) e pelo uso de materiais ilustrativos, há a possibilidade de competição visual entre o vídeo narrativo da história e a janela de Libras o que pode fazer com que a criança surda tenha o olhar atento para apenas uma das duas janelas. Com a história sendo contada na parte superior e a tradução na parte inferior, a criança surda pode, por uma lógica de apreensão da visualidade variar a direção do olhar para perceber a sincronia gestual do contador e da língua de sinais do tradutor.

Em outra proposta, o grupo da primeira turma do curso optou por diminuir a janela do tradutor e colocá-la à direita, dando maior visibilidade ao contador, conforme pode-se ver no recorte e depoimento abaixo: 


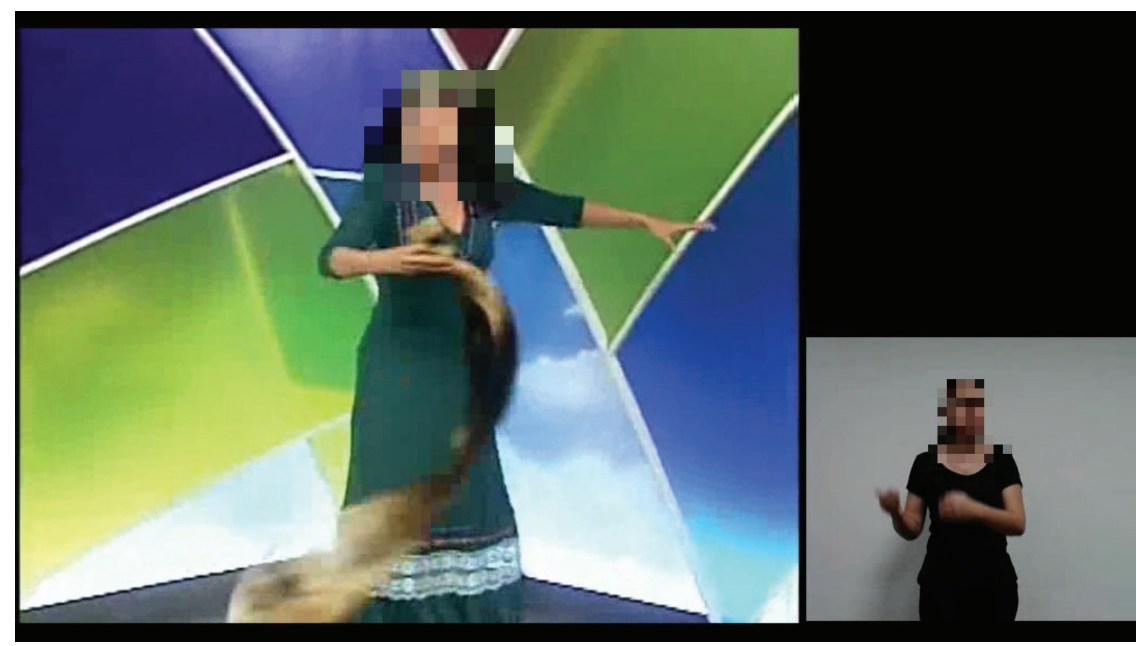

Escolbemos o tamanho da janela para que a LIBRAS ficasse clara para o surdo que fosse assistir, visto que é uma bistória infantil com uso de muitos classificadores que precisavam ser bem compreendidos visualmente. Não sobrepomos a tradução à tela da bistória para que não tirasse a visibilidade do vídeo original, o qual apresenta a bistória contada com auxílio de um lenço representando a cobra e considerei este fator importante para a compreensão do surdo, ou seja, o posicionamento da interpretação permite que o surdo faça a comparação visual entre a interpretação e a bistória contada.

\section{Depoimento grupo contação de histórias - turma 1}

Esta proposta foi sustentada com o argumento da comparação dos elementos verbo-visuais da história pelo público-alvo. Pelo fato de a contadora utilizar acessórios visuais para representar personagens da história, os tradutores do grupo acharam melhor dar maior visibilidade ao vídeo diminuindo suas dimensões, mas deixando-o maior que o vídeo da janela de Libras. Todavia, percebe-se que não há sobreposição da janela no vídeo o que pode dar certo conforto para quem está assistindo, seja porque a sobreposição evita que informações do vídeo fonte sejam perdidas, seja porque o descolamento da janela permite maior compreensão da língua de sinais durante a visualização. Se o enunciado, na perspectiva bakhtiniana, é visto para além da dimensão linguística sendo, nesse sentido, o extralinguístico a centralidade da sua realização e produção de sentidos, isto é, "do ponto de vista dos objetivos extralinguísticos do enunciado todo, o linguístico é apenas um meio" (BAKHTIN, 2010, p. 313), a consideração, por parte do grupo, dos aspectos verbovisuais da contação de história responde à peculiaridade do gênero em questão. 
São, portanto, "as formas do enunciado, e não da língua, que desempenham o papel essencial de consciência e na compreensão da realidade" (MEDVIEDÉV, 2012, p. 198).

\section{CONSIDERAÇÕES FINAIS}

A discussão realizada neste artigo visou contribuir diretamente com o papel da língua de sinais em materiais audiovisuais e suas devidas aplicações e transposições didáticas na formação de tradutores para atuar com essa demanda. Procurou-se, também, tensionar a ideia de que a janela de Libras é, apenas, um recurso acessibilidade transcritivo como se a simples colocação dessa janela fosse suficiente para a compreensão da totalidade da materialidade audiovisual pelo público surdo. Se o objetivo de um recurso de acessibilidade é oferecer o acesso à informação de forma multissensorial, deve-se levar em consideração que a visualidade não é só um canal de recepção de informações para os surdos usuários da língua de sinais e, por isso, a janela de Libras deve ser discutida não pela sua obrigatoriedade, apenas, mas pela sua relação dialógica e dialética com o vídeo como um todo. A lógica de funcionamento da visualidade é, também, uma orientação do gênero, quando se trata de práticas tradutórias intermodais, uma vez que a materialidade audiovisual será, sempre, verbo-visual.

Decerto que a discussão sobre os formatos das janelas aqui realizadas antecipam uma realidade ainda inexistente. Até o momento, o que se tem visto, de materiais didáticos às propagandas político-partidárias, é a implantação da janela por obediência à uma determinação legal e não à consideração, de fato, dos surdos enquanto interlocutores da cultura audiovisual no contexto brasileiro. Entretanto, quando os prestadores do serviço de tradução começarem a discutir os processos tradutórios considerando a totalidade discursiva do texto fonte e usarem a verbovisualidade como argumento para apresentar aos contratantes o papel da janela de Libras, acontecerão mudanças significativas na produção, recepção, interlocução e circulação desse recurso. Esperamos que a realidade das janelas de Libras em materiais audiovisuais ganhe outra dimensão por meio de uma discussão conjunta entre os surdos, enquanto público-alvo desse recurso, tradutores, editores e produtores de vídeo. Enquanto isso não acontece, vamos antecipando e preparando, nos cursos de formação existente de tradutores e de intérpretes, o necessário debate sobre as práticas tradutórias e interpretativas em materiais audiovisuais. 


\section{REFERÊNCIAS BIBLIOGRÁFICAS}

ALBRES, N. A. (2015a).Gesto-visualidade no processo de tradução de literatura infantojuvenil: marcas do discurso narrativo. Translatio. Porto Alegre, n. 9, 2015a. Disponível em: http://seer.ufrgs.br/index.php/translatio/article/view/51669

ALBRES, N. A. (2015b). Tradução intersemiótica de literatura infanto-juvenil: vivências em sala de aula. Cadernos de Tradução. Florianópolis, v. 35, nº especial 2, p. 387-486. Disponível em: http://dx.doi.org/10.5007/2175-7968.2015v35nesp2p387

ARBOLEYA, V.; BRINGMANN, D. (2008). Literatura infantil, contação de histórias e mídia: alternativas metodológicas e prática pedagógica. Anais do $1^{\circ}$ Simpósio Nacional de Educação, XX Semana da Pedagogia, Cascavel. Disponível em: http://www.unioeste.br/ cursos/cascavel/pedagogia/eventos/2008/1/Artigo\%2036.pdf

ABNT. NBR 15.290 - (2010). Acessibilidade em comunicação na televisão. Rio de Janeiro: Associação Brasileira de Normas Técnicas. Disponível em: http://www.crea-sc.org. br/portal/arquivosSGC/NBR\%2015290.pdf

BAKHTIN, M. M. (2013a). Problemas da poética de Dostoieuski. Trad. Paulo Bezerra. 5a. ed. Rio de Janeiro: Editora Forense.

BAKHTIN, M. M. (2010b). Os gêneros do discurso. In: Estética da Criação Verbal. Trad. Paulo Bezerra São Paulo: Martins Fontes, [1952-53].

BAKHTIN, M. (VOLOCHÍNOV). (2009). Marxismo e filosofia da linguagem: problemas fundamentais do método sociológico na ciência da linguagem. Trad. Michel Lahud e Yara Frateschi Vieira. 13 ed. São Paulo: Hucitec.

BEZERRA, P. (2015). Tradução, arte e diálogo. Bakbtiniana, São Paulo, 10 (3): 235-251, Set./Dez.

BRAIT, B. (2013). Olhar e ler: verbo-visualidade em perspectiva dialógica. Bakbtiniana, São Paulo, 8 (2): 43-66.

BRAIT, B. (2008). Análise e teoria do discurso. In: BRAIT, B. (Org.) Bakbtin, outros conceitoschave. São Paulo: Editora Contexto.

BRAIT, B.; PISTORI, M. H. C. (2012). A produtividade do conceito de gênero em Bakhtin e o Círculo. Alfa, São Paulo, v. 56, p. 371-401.

BRAIT, B. (2010). Literatura e outras linguagens. São Paulo: Contexto. 
BRASIL. Decreto 7.612 de 17 de novembro de 2011. Institui o Plano Nacional dos Direitos da Pessoa com Deficiência - Plano Viver sem Limite. Disponível em: http://www.planalto.gov. br/ccivil_03/_Ato2011-2014/2011/Decreto/D7612.htm

BRASIL. Lei no 10.098, de 19 de dezembro de 2000. Estabelece normas gerais e critérios básicos para a promoção da acessibilidade das pessoas portadoras de deficiência ou com mobilidade reduzida, e dá outras providências. Disponível em: http://www.planalto.gov.br/ccivil_03/LEIS/ L10098.htm\# art18

BRASIL. Decreto 5.626, de 22 de dezembro de 2005. Regulamenta a Lei $n^{0}$ 10.436, de 24 de abril de 2002, que dispõe sobre a Lingua Brasileira de Sinais - Libras, e o art. 18 da Lei $n^{0}$ 10.098, de 19 de dezembro de 2000. Disponível em: <http://www.planalto.gov.br/ccivil_03/_ato20042006/2005/decreto/d5626.htm> Acesso em: 20 de janeiro de 2010.

BRASIL. Estatuto da pessoa com deficiência - Brasília: Senado Federal, Coordenação de Edições Técnicas, 2015. Disponível em: https://www2.senado.leg.br/bdsf/bitstream/ handle/id/513623/001042393.pdf? sequence $=1$

BRASIL. Lei $N^{0}$ 13.146, de 6 de julho de 2015. Institui a Lei Brasileira de Inclusão da Pessoa com Deficiência (Estatuto da Pessoa com Deficiência). Disponível em: http://www.planalto.gov. br/ccivil_03/_ato2015-2018/2015/lei/113146.htm

BRITO, R. F. (2012). Modelo de Referência para Desenvolvimento de Artefatos de Apoio ao Acesso de Surdos ao Audiovisual. (Tese). Doutorado em Engenharia e Gestão do Conhecimento. Universidade Federal de Santa Catarina, Florianópolis.

CAMARGO, L. D. V. L.; GAROFALO, S.; COURA-SOBRINHO, J. (2011). Migrações da aula presencial para a videoaula: uma análise da alteração de médium. Quaestio. Sorocaba, SP, v. 13, n. 2, p. 79-91. Disponível em: http://docplayer.com.br/9876868Migracoes-da-aula-presencial-para-a-videoaula-uma-analise-da-alteracao-demidium-1.html

CLOT, Y. (2007). A função psicológica do trabalbo. Trad. Adail Sobral. Petrópolis: Editora Vozes.

FAÏTA, D. (2002). Análise das práticas linguageiras em situações de trabalho: uma renovação metodológica imposta pelo objeto. In: SOUZA-E-SILVA, M. C.; FAITA, D. (Org.). Linguagem e trabalbo: construção de objetos de análise no Brasil e na França. São Paulo: Cortez. 
FARIA, N. G.; SILVA, D. C. (2016). Legendas e janelas: questão de acessibilidade. Revista Sinalizar, v.1, n.1, p. 65-77. Disponível em: https://www.revistas.ufg.br/revsinal/ article/view/36156

FELICIO. (2013). O surdo e a contação de histórias - análise da interpretação simultânea do conto "sinais no metrô". (Dissertação). Mestrado em Estudos da Tradução. Universidade Federal de Santa Catarina, Florianópolis.

FIORIN, J. L. (2016). As astúcias da enunciação: as categorias de pessoa, espaço e tempo. $3^{\mathrm{a}} \mathrm{Ed}$. São Paulo: Editora Contexto.

GRILLO, S. (2008). Esfera e Campo. In: BRAIT, B. (Org.) Bakbtin: outros conceitos-chave. São Paulo: Contexto.

JAKOBSON, R. (2010). Linguística e comunicação. Trad. Izidoro Blikstein e José Paulo Paes $22^{\mathrm{a}}$ Ed. São Paulo: Editora Cultrix.

LIMA, A. P. (2014). Procedimentos teórico-metodológicos de estudo de gêneros do discurso: atividade e oralidade em foco. In: BRAIT, B.; MAGALHÃES, A. S. (Org) Dialogismo: teoria e $(m)$ prática. São Paulo: Terracota.

MARTINS, V. R. O; NASCIMENTO. (2015). Da formação comunitária à formação universitária (e vice e versa): novo perfil dos tradutores e intérpretes de língua de sinais no contexto brasileiro. Cadernos de Tradução, Florianópolis, v. 35, no especial 2, p. $78-112$.

MEDVIÉDEV, P. N. (2012). O método formal nos estudos literários: introdução crítica a uma poética sociológica. Trad. Sheila Camargo Grillo e Ekaterina Vólkova Américo. São Paulo: Contexto.

MOURA-VIEIRA, M. A. (2012). A atividade e o discurso na clínica: uma análise dialógica do trabalho médico. Amsterdam/Recife: CreatSpace Independet Publishing Platform.

NASCIMENTO, M. V. B. (2016a) Formação de intérpretes de libras e língua portuguesa: encontros de sujeitos, discursos e saberes. (Tese). Doutorado em Linguística Aplicada e Estudos da Linguagem. Pontifícia Universidade Católica de São Paulo, São Paulo.

NASCIMENTO, M. V. B. (2011). Interpretação da língua brasileira de sinais a partir do gênero jornalístico televisivo: elementos verbo-visuais na produção de sentidos. (Dissertação) Programa de Linguística Aplicada e Estudos da Linguagem. São Paulo: LAEL/PUCSP. 
NASCIMENTO, V. (2016b). Da norma legislativa à atividade interpretativa: acessibilidade comunicacional de surdos à mídia televisiva. In: SILVA, A. A.; ALBRES, N. A.; RUSSO, A. (Orgs.) Diálogos em estudos da tradução e interpretação de língua de sinais. Curitiba: Editora Prismas.

NASCIMENTO, V. (2014). Gêneros do discurso e verbo-visualidade: dimensões da linguagem para a formação de tradutores/intérpretes de Libras/Português. In: BRAIT, B.; MAGALHÃES, A. S. Dialogismo: teria e(m) prática. São Paulo: Terracota.

NICHOLS, J. (2016). Literatura Surda: além da língua de sinais. (Dissertação). Mestrado em Educação. Universidade Estadual de Campinas, Campinas.

OUSTINOFF, M. (2011).Tradução: história, teorias e métodos. Trad. Marco Marcionilo. São Paulo: Parábola Editorial.

PAGURA, R. (2003). A interpretação de conferências: interfaces com a tradução escrita e implicações para a formação de intérpretes e tradutores. DELTA, 19, Vol. Especial, São Paulo, PUC-SP.

QUADROS, R. M.; STUMPF, M. R. (2015). Letras Libras EaD. In: QUADROS, R. M. (Org). Letras Libras: ontem, hoje e amanhã. Florianópolis: Editora da UFSC.

QUADROS, R. M.; SEGALA, R. R. (2015). Tradução intermodal, intersemiótica e interlinguística de textos escritos em português para a libras oral. Cadernos de Tradução, Florianópolis, v. 35, no especial 2, p. 354-386, jul-dez.

QUADROS, R. M. (2006). Efeitos de modalidade de língua: as línguas de sinais. Educação Temática Digital, Campinas, v. 7, p. 168-178.

RODRIGUES, R. (2015). Interpretação de Libras e Português no contexto empresarial (Palestra). I Semana do Curso de Bacharelado em Tradução e Interpretação em Libras e Língua Portuguesa. Universidade Federal de São Carlos.

ROSA, F. S. (2006). Literatura surda: criação e produção de imagens e textos. ETD - Educação Temática Digital, Campinas, v.7, n.2, p.58-64, jun. Disponível em: http://periodicos. sbu.unicamp.br/ojs/index.php/etd/article/view/791

SEGALA, R. R. (2010). Tradução intermodal e intersemiótica/interlinguística: português escrito para a língua de sinais. (Dissertação). Mestrado em Estudos da Tradução. Universidade Federal de Santa Catarina, Florianópolis. 
SOBRAL, A. (2009). Do dialogismo ao gênero: as bases do pensamento do Círculo de Bakhtin. Campinas: Mercado das Letras.

TORRES, E. F.; MAZZONI, A. A. O direito de acesso à televisão nos meios televisivos: onde está a inclusão? Brasília: Inclusão Social. v. 2, n. 1, p. 73-82, out. 2006/mar. 2007. Disponível em: http://revista.ibict.br/inclusao/article/view/1592/1799

Recebido: 03/05/2017

Aceito: 09/08/2017 